\title{
STUDY ON ANTIOXIDANT AND CYTOTOXIC PROPERTIES OF OLEA DIOICA ROXB. CRUDE EXTRACT AND ITS PURE COMPOUND COLLECTED FROM WESTERN GHATS, KARNATAKA, INDIA
}

\author{
ASHWATHANARAYANA R*, RAJA NAIKA \\ Department of PG Studies and Research in Applied Botany, Jnanasahyadri, Kuvempu University, Shankaraghatta - 577 451. Shimogga, \\ Karnataka, India. Email: ashwinjamadagni497@gmail.com \\ Received: 17 October 2016, Revised and Accepted: 28 October 2016
}

ABSTRACT

Introduction: Olea dioica Roxb. an important medicinal tree plants used by local siddha tribes, belongs to the family Oleaceae. The parts such as leaves, bark, root, and fruits used in the traditional medicine to cure skin diseases, rheumatism, fever, and cancer.

Objectives: The anti-oxidant experiment by metal chelating activity, superoxide radicals, hydroxyl radical, 2,2-diphenyl-2-picrylhydrazyl radicals, 2,2-azino-bis(3-ethylbenzothiazoline)-6-sulfonic acid radical scavenging assays with in vitro cytotoxicity was tested using trypan blue dye exclusion technique and 3-(4, 5 dimethylthiazole-2yl)-2, 5-diphenyltetrazolium bromide assay was conducted.

Results: Anti-oxidant experiments revealed that the bark ethanolic extract of the $O$. dioica plant parts has excellent radical scavenging activity and its extracted pure compound, Benzene ethanol, 4-hydroxy-alcohol, showed excellent radical scavenging activity higher than the standards used. In vitro cytotoxicity experiments revealed that bark ethanolic extract has excellent cytotoxicity activity and its pure compound benzene-ethanol, 4-hydroxyalcohol also showed excellent activity which is comparable with the standard curcumin.

Conclusion: 0 . dioica bark could be exploited as a valuable source of antioxidant and cytotoxic agent for pharmaceutical industry.

Keywords: Olea dioica Roxb, Metal chelating, Superoxide radicals, Hydroxyl radical, 2,2-diphenyl-2-picrylhydrazyl radicals, 2,2-azinobis(3-ethylbenzothiazoline)-6-sulfonic acid radical scavenging, Trypan blue, 3-(4, 5 dimethylthiazole-2yl)-2, 5-diphenyl tetrazolium bromide assay, Benzene ethanol, 4-hydroxy-alcohol.

(c) 2017 The Authors. Published by Innovare Academic Sciences Pvt Ltd. This is an open access article under the CC BY license (http://creativecommons. org/licenses/by/4. 0/) DOI: http://dx.doi.org/10.22159/ajpcr.2017.v10i2.15727

\section{INTRODUCTION}

In biological systems, most of the free radicals are derivatives of oxygen such as superoxide, hydrogen peroxide, hydroxyl radical, or derivatives of nitrogen-like nitric oxide and peroxynitrite [1].

Reactive oxygen species were the major cause for mutagenesis and carcinogenesis [2]. They also induce toxic effects such as inactivation of enzymes and alteration of intracellular oxidation-reduction state [3]. It can also generate many types of DNA modifications and chromosome aberrations leading to carcinogenesis [4].

The free radicals damage on the cell/tissues are neutralized by antioxidants such as á-tocopherol, carotenoids, glutathione, thiols, vitamin $\mathrm{C}$, by scavenging and decreasing their formation. In plants, several natural compounds exhibit antioxidant and/or radical scavenger properties. They possess low molecular weight, and the antioxidant mechanism is very complex [5].

Most of the natural phenolic compounds have potential antioxidants properties. Many scientific reports confirm the positive antioxidant potential phenolic compounds extracted from different plant species. There is positive linear correlation between the total phenolic content of the plant part to the antioxidant properties [6].

Medicinal plants have been used for centuries as remedies for human diseases and offer a new source of biologically active chemical compound as antimicrobial agents. Medicinal plants are the richest bio-resources of drugs of traditional medicinal systems, modern medicines, nutraceuticals, food supplements, folk medicines, pharmaceuticals, intermediate and chemical entitled for synthetic drugs [7].

Several medicinal plants have been evaluated for possible antimicrobial activity and to get remedy from a variety of ailments of microbial origin [8].

Many of the plant extracts are extensively used as medicinal compounds for the treatment of various ailments in different parts of the world, especially in under developing and developing countries [9-11].

Secondary metabolites such as flavonoids [12], terpenoids [13], steroids [14], saponins [15], glycosides [16], and phenols have the pharmacological properties which are extracted from higher plants.

The Indian subcontinent is a vast repository of medicinal plants that are used in traditional medical treatments which also forms a rich source of knowledge [17]. India is one of the megadiversity centers in the planet having a diverse medicinal plant species which is unexplored most of them are endemic. India shares approximately $13 \%$ of world's biodiversity, one among 17 mega diversity centers. Among the 34 hotspots in the world India have 4 hotspots, namley, Eastern Himalaya, indo-Burma, Western Ghats, Andaman, and Nicobar Island. The various indigenous systems use several plant species to treat different ailments [17]. In India, around 20,000 medicinal plant species have been recorded recently but more than 500 traditional communities use about 800 plant species for curing different diseases [18].

Western Ghats (also known as Sahyadri) is a mountain range that runs parallel to the Western coast of the Indian peninsula, located entirely 
in India. The range starts near the border of Gujarat and Maharashtra runs approximately $1600 \mathrm{~km}$ through the states of Maharashtra, Goa, Karnataka, Kerala, and Tamil Nadu ending at Kanyakumari at the southern tip of India [19].

The study conducted by the Indian Institute of Remote Sensing by Satellite image interpretation discovered that there are four major forest types in the Western Ghats: Evergreen, semi-evergreen, moist deciduous, and dry deciduous, covers approximately $20 \%$ of the total Western Ghats. Among the four, moist deciduous forests occupy the largest part followed by semi-evergreen, dry deciduous, and evergreen. The majority of the area under moist forest types will come under the territory of Karnataka and Kerala combined together forms $80 \%$ of the evergreen forest and 66 percent of the moist deciduous forests of total Western Ghats area. The highest levels of endemism are found in the Western Ghats, in evergreen, and semi-evergreen forests have high levels of tree diversity and endemism. The dominant species include: Terminalia paniculata, Aporusa lindleyana, Olea dioica, Mesua ferrea, Vateria indica, Elaeocarpus tuberculatus, Celtis timorensis, Hopea parviflora, Lagerstroemia microcarpa, Holigarna arnottiana, Hydnocarpus laurina, Memcylon umbellatum, Pavetta crassicaulis, Pavetta indica, and Careya arborea [20].

\section{EXPERIMENTAL MEDICINAL PLANT AND DESCRIPTION}

O. dioica Roxb. Scientific classification

Kingdom: Plantae

Phylum: Tracheophyta

Class: Magnoliopsida

Order: Lamiales

Family: Oleaceae

Genus: Olea

Species: dioica Roxb.

O. dioica Roxb. is an important folklore ethnomedicinal tree, belongs to the family of Oleaceae. Trees measures up to $15 \mathrm{~m}$ tall, in open evergreen to semi-evergreen, and moist deciduous forests, up to $1200 \mathrm{~m}$ altitude, distributed throughout the Western Ghats, India. The bark of the tree is brownish, rough; blaze pale brown. Young branchlets are subquadrangular, lenticel late, glabrous. Leaves are simple, opposite, decussate; petiole $0.6-1.3 \mathrm{~cm}$ long, canaliculate; lamina 7.5-17.5×2.3$7.5 \mathrm{~cm}$, elliptic to elliptic-oblong, apex gradually acuminate to subacute, base acute or attenuate, margin distantly serrate (with strong teeth) or entire, coriaceous to subcoriaceous, glabrous; midrib flat above, usually reddish when dry; secondary nerves 8-12 pairs; tertiary and higher order nerves obscure or slightly impressed. Inflorescence axillary divaricate panicles; flowers polygamodioecious, cream-white; pedicel $0.4 \mathrm{~cm}$ long. Fruit is drupe, ellipsoid, blue when ripe; one-seeded. Roots of the plant have medicinal properties and are used for the treatment of cancer and snake bite in siddha medicine. IIn Maharashtra, fruits of O. dioica Roxb. were used by the tribes in the treatment of skin disease. Bark and fruit paste are used in rheumatism; decoction of the bark is used to wash old wounds and given to counter fever [21]. Ripe fruits are traditionally used by the tribes in Kerala forest [22]. O. dioica leaf methanolic extract showed appreciable antibacterial and antifungal activity $[23,24]$.

The roots of the plant having ethno botanic medicinal properties used for cancer and snake bite treatment in siddha medicine [25]. In Maharashtra, the tribes use $O$. dioica Roxb. fruits in the treatment of various skin diseases [26]. Bark and fruit paste is used in the treatment of rheumatism; decoction of the bark is used to wash old wounds and given in fever, ripe fruits are traditionally used in the various treatment, by the tribes in Kerala forest [22].

Despite of many works on 0 . dioica, antioxidant and cytotoxicity properties have not been studied in details. Therefore, the aim of the study was to provide basic data on the antioxidant and cytotoxic study of $O$. dioica plant parts. Antioxidant was evaluated using superoxide radicals, hydroxyl radical, 2,2-diphenyl-2-picrylhydrazyl (DPPH) radicals, 2,2-azino-bis(3-ethylbenzothiazoline)-6-sulfonic acid (ABTS) radicals scavenging, and metal chelating activity, and in vitro cytotoxic effect was assessed using Ehrlich's ascites carcinoma (EAC) and Dalton's lymphoma ascites (DLA) two cancer cell lines.

\section{METHODS}

Plant collection and authentication

The bark and leaf materials of 0 . dioica Roxb. were collected from Shringeri Taluk, Karnataka in April 2014.(13.4198 ${ }^{\circ}$ N, 75.2567 E) (Fig. 1). The plant was identified by Prof. K G Bhat, Udupi, and a voucher specimen was conserved under the reference number $\mathrm{KU} / \mathrm{AB} / \mathrm{RN} / \mathrm{AS} / 001$.

\section{Plant preparation and extraction}

The samples were dried in shade for 20-25 days, mechanically powdered, and subjected to Soxhlet extraction using hexane, petroleum ether, chloroform, ethanol, and aqueous extracts [27]. The crude extracts were collected in air-tight plastic containers and stored in cool condition

\section{Chemicals required}

DPPH, ABTS, ascorbic acid, butylated hydroxyl anisole, ferrozine, gallic acid, ferrous chloride, Folin-Ciocalteu reagent, nitro blue tetrazolium sodium salt (NBT), nicotinamide adenine dinucleotide phosphate reduced, phosphate-buffered saline (PBS), and trichloroacetic acid (TCA). All other chemicals and solvents used were of analytical grade.

\section{Qualitative phytochemical screening for phenols and flavonoids Total phenolic content}

It is determined by the Folin-Ciocalteu method [28]. A dilute concentration of extract $(0.5 \mathrm{~mL})$ was mixed with $0.5 \mathrm{ml}$ of $1: 1$ diluted Folin-Ciocalteu reagent and $4 \mathrm{ml}$ of sodium carbonate (I M). The mixtures were allowed to stand for 15 minutes, and the absorbance was measured against the blank at $765 \mathrm{~nm}$ colorimetrically. A standard curve was plotted using different concentrations of Gallic acid (standard, $0-1000 \mu \mathrm{g} / \mathrm{ml}$ of ethanol). Total phenolic content of solvent extracts was estimated as $\mu$ g gallic acid equivalents $/ \mathrm{mg}$ of extract. All samples were analyzed in triplicate, and the results were averaged.

\section{Determination of total flavonoid content}

Total flavonoid content was determined [29] using quercetin as standard. Briefly, $5 \mathrm{ml}$ of extracts ( $200 \mu \mathrm{g})$ in millipore water was mixed with $300 \mu \mathrm{l}$ of sodium nitrite (5\%) and $300 \mu \mathrm{l}$ of aluminum chloride $(10 \%)$, this reaction mixture was incubated at room temperature for 6 minutes followed by the addition of $2 \mathrm{ml}$ of sodium hydroxide $(1 \mathrm{M})$. Later, the volume in each test tube was made up to $10 \mathrm{ml}$ by adding $2.4 \mathrm{ml}$ of millipore water. Absorbance was measured against the blank at $510 \mathrm{~nm}$. Total flavonoid content of the extract was expressed in terms of equivalent to quercetin (EQ, $\mu \mathrm{g} / \mathrm{mg}$ of dry mass).

\section{In vitro antioxidant activity}

\section{Total antioxidant capacity}

Total antioxidant capacity of extracts was done according to the method of Prieto 1999 [30]. $300 \mu \mathrm{l}$ of extracts at different concentrations (0-160 $\mu \mathrm{g})$ was combined with $3 \mathrm{ml}$ of reagent mixture $(4 \mathrm{mMammonium}$ molybdate, $0.6 \mathrm{M}$ sulfuric acid, and $28 \mathrm{mM}$ of sodium phosphate). The tubes were capped and kept for incubation at $95^{\circ} \mathrm{C}$ for 90 minutes, after cooling to room temperature the absorbance of the content was measured at $695 \mathrm{~nm}$ against the blank. The total antioxidant capacity of each extract is expressed as equivalents of ascorbic acid.

\section{Total reductive capability}

Total reduction capability of extracts was done according to the method of Oyaizu 1986 [31]. The different concentration of extracts (0-300 $\mu \mathrm{g})$ in $1 \mathrm{ml}$ of water was mixed with $2.5 \mathrm{ml}$ of phosphate buffer $(0.2 \mathrm{M}$, $\mathrm{pH} 6.5$ ) and $2.5 \mathrm{ml}$ of potassium ferricyanide (1\%). The mixtures were incubated at $50^{\circ} \mathrm{C}$ for 20 minutes, and $2.5 \mathrm{ml}$ of $10 \%$ TCA were added. Then, the mixture was centrifuged for 10 minutes at $3000 \mathrm{rpm} .2 .5 \mathrm{ml}$ 
of water and $0.5 \mathrm{ml}$ of ferric chloride $(0.1 \%)$ was added to $2.5 \mathrm{ml}$ of supernatant. The absorbance was measured at $700 \mathrm{~nm}$ against blank. Higher absorbance of the reaction mixture indicated greater reducing power. Total reducing capacity of each extract is expressed as equivalents of quercetin.

\section{Scavenging of superoxide radicals}

Superoxide radical scavenging activity was determined by the NBT reduction method [32]. The reaction mixture contained $6 \mu \mathrm{M}$ EDTA, $0.0015 \% \mathrm{NaCN}, 2 \mu \mathrm{M}$ riboflavin, $50 \mu \mathrm{M}$ NBT, various concentrations of extract, and phosphate buffer (67 mM, pH 7.8) in a final volume of $3 \mathrm{~mL}$. The tubes were uniformly illuminated with an incandescent lamp for 15 minutes, and the optical density was measured at $560 \mathrm{~nm}$ before and after illumination. The percentage inhibition of superoxide radical generation was evaluated by comparing the absorbance values of control and experimental tubes.

\section{Scavenging of hydroxyl radical}

Hydroxyl radicals generated from $\mathrm{Fe} 2+$ /ascorbate/H system degrades deoxyribose producing thiobarbituric acid reacting substance (TBARS) [33]. The efficacy of the extracts to inhibit TBARS formation was assessed. The reaction mixture contained $2.8 \mathrm{mM}$ deoxyribose, $0.1 \mathrm{mM} \mathrm{FeCl}_{3}, 0.1 \mathrm{mM}$ EDTA, $1 \mathrm{mM} \mathrm{H} \mathrm{O}_{2}, 0.1 \mathrm{mM}$ ascorbic acid, $20 \mathrm{mM} \mathrm{KH_{2 }} \mathrm{PO}_{4}-\mathrm{KOH}(\mathrm{pH} 7.4$ ), and various concentrations of extracts in a final volume of $1 \mathrm{~mL}$. The reaction mixture was incubated for $1 \mathrm{hr}$ at $37^{\circ} \mathrm{C}$. The TBARS formed was measured by the method of Ohkawa et al. 1979, [34] and the percentage inhibition was calculated from the optical measurements of control and experimental tubes.

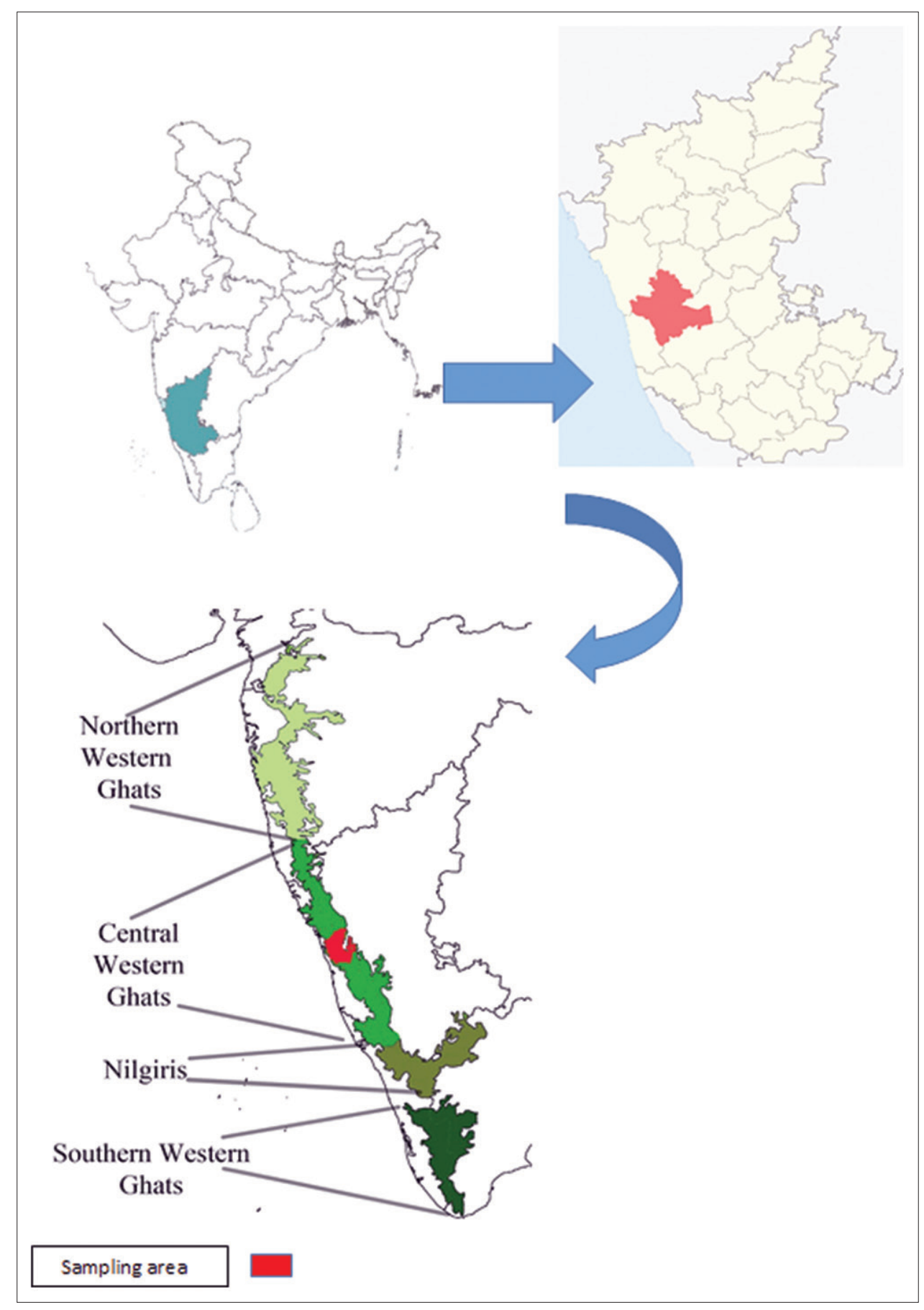

Fig. 1: Sampling site details and location 


\section{Scavenging of DPPH radicals}

Stable radical, DPPH in methanol was used as substrate to evaluate antioxidant activity. The method is based on the reduction of DPPH radical in the presence of hydrogen donating antioxidants leading to the formation of a non-radical form DPPH-H by the reaction. DPPH in its radical form has an absorption peak at $515 \mathrm{~nm}$ which disappeared on the reduction by antioxidant compounds. Absorbance was measured 20 minutes after the reaction was started.

Radical scavenging activity was calculated using the following formula:

Percentage inhibition $=\frac{\begin{array}{l}\text { Absorbance of control }- \\ \text { Absorbance of test }\end{array}}{\text { Absorbance of control }} \times 100$

$\mathrm{IC}_{50}$ value was calculated using the following formula:

$$
\mathrm{IC}_{50}=\frac{\text { Sum of extract concentration }}{\text { Sum of percentage of inhibition at diff. conc. }} \times 50
$$

\section{Scavenging of ABTS radicals}

ABTS radical scavenging activity of the extract was determined by the method described by Alzoreky and Nakahara 2001 [35]. The principle involves the oxidation of ABTS to its cation radicals by ferryl myoglobin formed in the reaction of $\mathrm{H}_{2} \mathrm{O}_{2}$ and metmyoglobin. Briefly, the stock solutions of $500 \mu \mathrm{M}$ ABTS diammonium salt, $400 \mu \mathrm{M}$ myoglobin (MbIII), $740 \mu \mathrm{M}$ potassium ferricyanide, and $450 \mu \mathrm{M} \mathrm{H}_{2} \mathrm{O}_{2}$ were prepared in PBS ( $\mathrm{pH}$ 7.4). Metmyoglobin was prepared by mixing equal volumes of myoglobin and potassium ferricyanide solutions. The reaction mixture $(2 \mathrm{~mL})$ contained ABTS $(150 \mu \mathrm{M})$, MbIII $(2.25 \mu \mathrm{M})$, and varying concentrations of extracts in PBS. The reaction was initiated by adding $75 \mu \mathrm{M} \mathrm{H}_{2} \mathrm{O}_{2}$, and oxidation reaction was monitored at $734 \mathrm{~nm}$.

\section{Metal chelating activity}

The chelation of ferrous ions was determined according to the method of Dinis et al. 1994 [36]. About $3 \mathrm{ml}$ of extracts at different concentrations were taken in different test tubes followed by the addition of $50 \mu \mathrm{l}$ of ferrous chloride $(2 \mathrm{mM})$. The reaction was initiated by the addition of $20 \mu \mathrm{L}$ ferrozine $(5 \mathrm{mM})$, and then the mixture was shaken vigorously and allowed to stand for $10 \mathrm{~min}$ at room temperature. After equilibrium, the absorbance of the solution was measured at $562 \mathrm{~nm}$ against the blank. EDTA was used as standard for comparison. Percentage of inhibition and $\mathrm{IC}_{50}$ value was calculated using Equations (1 and 2).

\section{In vitro cytotoxicity assay \\ Cell lines}

EAC

Paul Ehrlich found the initial tumor for the EAC in 1905. The ascites variant was obtained on 1932 by intraperitonial transplantation of Ehrlich's solid adenocarcinoma.

DLA

The initial tumor for the DLA arose as a spontaneous carcinoma in the thymus of mice in 1947.

The cell lines were obtained from Amala Cancer Research Centre, Thrissur.

\section{Trypan blue dye exclusion technique}

Any compound, which is cytotoxic to cells, inhibits the cell proliferation and kills the cells. Trypan blue [37] can penetrate into the dead cells and give it blue color. This method gives an exact number of dead and viable cells. Cells were aspirated from the peritoneal cavity of tumor-bearing mice and it was washed three times using PBS. The viability of cells was checked using trypan blue (cell viability should be above $98 \%$ ).
The cell suspension was added to tubes containing various concentrations of the test compounds, and the volume was made up to $1 \mathrm{ml}$ using PBS. Control tubes containing only cell suspension. These assay mixtures were incubated for $3 \mathrm{hrs}$ at $370 \mathrm{C}$, and then $1 \mathrm{ml}$ of trypan blue was added after incubation, and the number of the dead cell was counted using a hemocytometer [38]. The percentage cytotoxicity was calculated using the following equation:

$$
\% \text { Cytotoxicity }=\frac{\text { Number of dead cells }}{\text { Number of viable cell }+ \text { Number of dead cells }} \times 100
$$

\section{3-(4, 5 dimethylthiazole-2yl)-2, 5-diphenyl tetrazolium bromide (MTT) assay}

The ability of the cells to survive a toxic insult is the basis of most cytotoxic assays. This assay is based on the assumption that dead cells or their products do not reduce tetrazolium. The assay depends both on the mitochondrial activity per cell and number of cells present. The cleavage of MTT to a blue formazan derivative by living cells is clearly a very effective principle on which the assay is based. The principle involved is the cleavage of tetrazolium salt, MTT in to a blue colored product (formazan) by mitochondrial enzyme succinate dehydrogenase. The amount of cells was found to be proportional to the extent of formazan production by the cells used [39]. Cells were seeded in a 96-well flat-bottom plate (5000 cells/well) and permitted to adhere for $24 \mathrm{hrs}$ at $37^{\circ} \mathrm{C}$ with $5 \% \mathrm{CO}_{2}$ atmosphere. Different drug concentration was added and incubated further for $48 \mathrm{hrs}$. Before $4 \mathrm{hrs}$ of the completion of incubation, $20 \mu \mathrm{l}$ of MTT $(5 \mathrm{mg} / \mathrm{ml})$ was added. Dead cell percentage was determined using an ELISA plate reader set to record absorbance at $570 \mathrm{~nm}$. The percentage growth inhibition was calculated using the formula given below [40].

$\%$ Growth inhibition $=100-\frac{\text { OD of individual test group }}{\text { OD of control group }} \times 100$

\section{RESULTS}

Qualitative preliminary phytochemical analysis

In all the extract used, maximum yield of compounds obtained in ethanol and aqueous extracts. The preliminary phytochemical investigation showed that of leaf ethanolic extract revealed the presence of flavonoids, alkaloids, glycosides, sterols, saponins and absence of terpenoids, tannins and in ethanolic bark extract confirms the positive results for flavonoids, glycosides, terpenoids, tannins, alkaloids, and saponins.

\section{Quantitative phenol and flavonoid analysis}

Total phenolic content in leaf and bark ethanolic extract was expressed as equivalent to gallic acid and was found to be $654.3 \pm 0.32$ and $329.22 \pm 0.13 \mu \mathrm{g} / \mathrm{mg}$ of dry samples, respectively. The total flavonoid content of samples was found to $385.1 \pm 0.95$ and $291 \pm 0.4 \mu \mathrm{g} / \mathrm{mg}$ of dry extract as EQ in samples, respectively.

\section{In vitro antioxidant properties}

\section{Total antioxidant and reductive capability}

Total antioxidant activity of both ethanolic crude extract and pure compound were shown significant antioxidant activity. The pure compound Benzene ethanol, 4-hydroxy- alcohol, activity is higher than to that of standard ascorbic acid.

However, ethanolic crude extract and pure compound have shown appreciable reductive capability when compared to standard quercetin. Like antioxidant activity, the reducing power of ethanolic crude extract and pure compound were increased with increasing concentration; hence, the pure compound Benzene ethanol, 4-hydroxy- alcohol can serve as free radical inhibitors or scavengers, which as much capable as standard used (Graphs 1-4). 


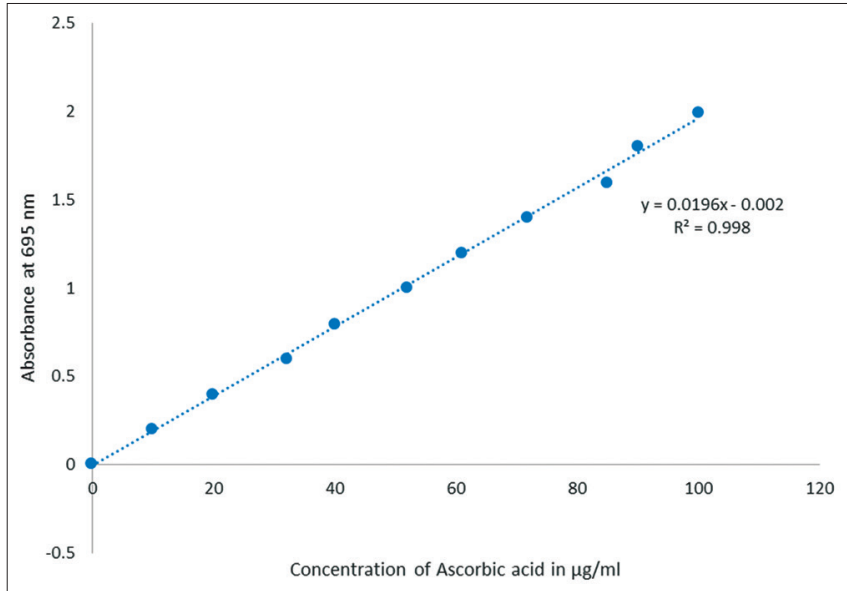

Graph 1: Total antioxidant activity

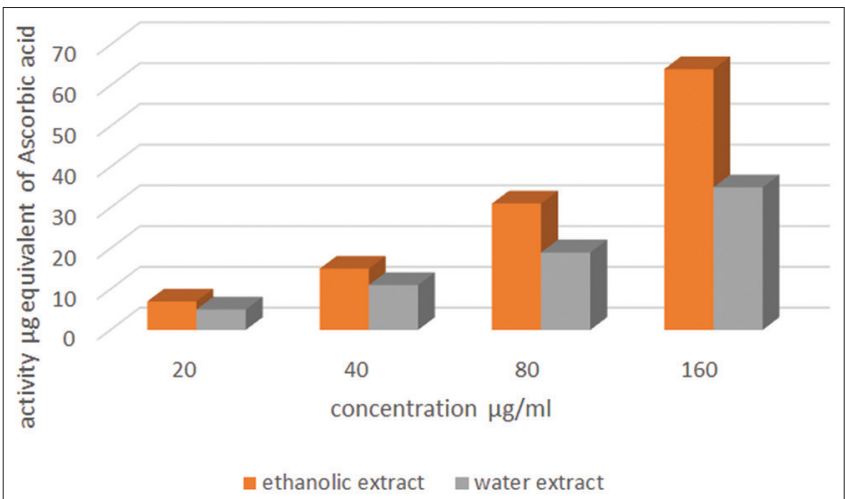

Graph 2: Total antioxidant properties of ethanol and water extract

\section{DPPH radical scavenging activity}

DPPH radical scavenging activity was expressed in terms of percentage of inhibition and $\mathrm{IC}_{50}$ values $(\mu \mathrm{g} / \mathrm{ml})$. By the experiment, it is revealed that leaf and bark aqueous crude extracts shows less scavenging activity compared with ethanolic crude leaf and bark extracts. Comparing to all the crude extracts $\left(\mathrm{IC}_{50}\right.$; DPPH: Leaf ethanolic extract: $69.12 \pm 0.30 \mu \mathrm{g} / \mathrm{ml}$, leaf aqueous extract: $90.96 \pm 0.21 \mu \mathrm{g} / \mathrm{ml}$ and bark aqueous extract: $107.14 \pm 1.48 \mu \mathrm{g} / \mathrm{ml}$ ), the bark ethanolic crude extract shows appreciated radical scavenging activity $\left(\mathrm{IC}_{50}\right.$; DPPH:63.77 \pm 0.39$)$, and pure compound benzene ethanol, 4-hydroxy-alcohol, which is extracted form bark ethanolic crude extract was showed excellent radical scavenging activity $\left(\mathrm{IC}_{50}\right.$; DPPH: $32.99 \pm 0.20 \mu \mathrm{g} / \mathrm{ml}$ ) showed excellent activity more than the standard ascorbic acid $\left(\mathrm{IC}_{50}\right.$; DPPH: $39.48 \pm 0.02 \mu \mathrm{g} / \mathrm{ml}$ ) (Tables 1 and 2).

\section{ABTS free radical scavenging activity}

ABTS radical scavenging activity was expressed in terms of percentage of inhibition and $\mathrm{IC}_{50}$ values $(\mu \mathrm{g} / \mathrm{ml})$. It is evident that leaf and bark ethanolic crude extracts show excellent ABTS radical scavenging activity compared to aqueous crude leaf and bark extracts. Comparing to all the crude extracts $\left(\mathrm{IC}_{50}\right.$; ABTS: Leaf ethanolic extract: $188.14 \pm 1.71 \mu \mathrm{g} / \mathrm{ml}$, leaf aqueous extract: $353.88 \pm 2.82 \mu \mathrm{g} / \mathrm{ml}$ and bark aqueous extract: $221.21 \pm 1.98 \mu \mathrm{g} / \mathrm{ml}$ ), the bark ethanolic crude extract shows appreciated radical scavenging activity $\left(\mathrm{IC}_{50}\right.$; ABTS: $129.41 \pm 3.08 \mu \mathrm{g} / \mathrm{ml}$ ), and pure compound benzene ethanol, 4-hydroxy- alcohol, was showed excellent radical scavenging activity $\left(\mathrm{IC}_{50}\right.$; ABTS: $60.38 \pm 0.34 \mu \mathrm{g} / \mathrm{ml}$ ) showed excellent activity more than the standard butylated hydroxylanisole $\left(\mathrm{IC}_{50} ; \mathrm{ABTS}: 66.92 \pm 0.36 \mu \mathrm{g} / \mathrm{ml}\right.$ ) (Tables 2 and 3 ).

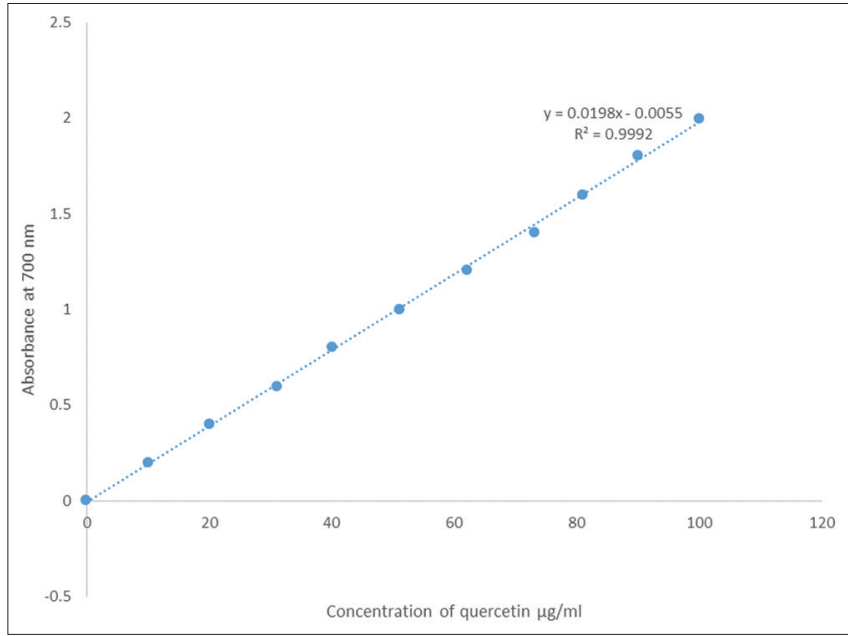

Graph 3: Total reductive properties

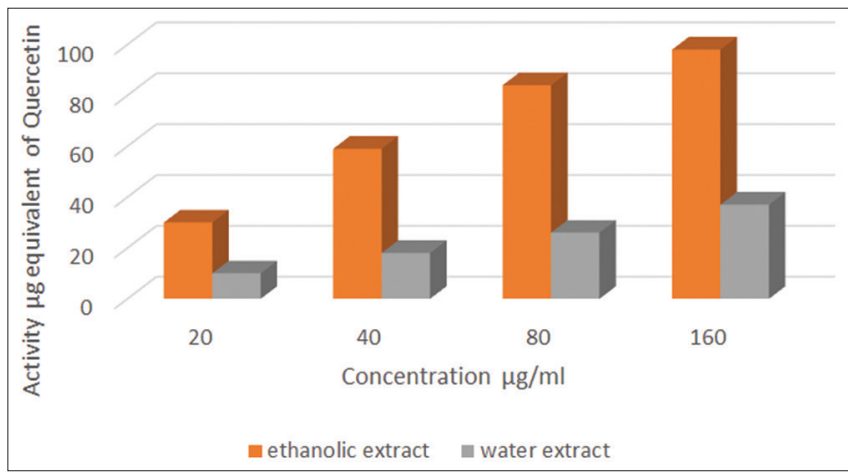

Graph 4: Total reductive properties of ethanolic and water extract

\section{Metal chelating activity}

In this experiment, both leaf and bark ethanolic crude extracts $\left(\mathrm{IC}_{50}\right.$; Leaf ethanol: $637.67 \pm 2.61 \mu \mathrm{g} / \mathrm{ml}$, Bark ethanol: $472.43 \pm 1.96 \mu \mathrm{g} / \mathrm{ml}$ ) showed excellent metal chelating activity compared to the leaf and bark aqueous crude extracts $\left(\mathrm{IC}_{50}\right.$; Leaf aqueous: $1639.12 \pm 2.87 \mu \mathrm{g} / \mathrm{ml}$, Bark aqueous: $1132.19 \pm 2.15 \mu \mathrm{g} / \mathrm{ml}$ ). The pure compound Benzene ethanol, 4-hydroxy-alcohol, showed excellent metal chelating activity (IC ${ }_{50}$; $201.52 \pm 2.43 \mu \mathrm{g} / \mathrm{ml})$ than the standard EDTA $\left(\mathrm{IC}_{50} ; 213.69 \pm 0.32 \mu \mathrm{g} / \mathrm{ml}\right)$ used (Tables 4 and 5).

\section{Superoxide radical scavenging activity (NBT)}

In superoxide radicals scavenging NBT reduction method, both leaf and bark aqueous crude extracts shows moderate activity $\left(\mathrm{IC}_{50}\right.$; Leaf aqueous: $344.97 \pm 2.77 \mu \mathrm{g} / \mathrm{ml}$, Bark aqueous: $299.38 \pm 2.49 \mu \mathrm{g} / \mathrm{ml}$ ) compared to leaf and bark ethanolic crude extracts $\left(\mathrm{IC}_{50}\right.$; Leaf ethanol: $262.14 \pm 3.18 \mu \mathrm{g} / \mathrm{ml}$, Bark ethanol: $232.76 \pm 1.15 \mu \mathrm{g} / \mathrm{ml}$ ). The pure compound Benzene ethanol, 4-hydroxy-alcohol showed excellent radical scavenging activity $\left(\mathrm{IC}_{50} ; 99.92 \pm 0.54 \mu \mathrm{g} / \mathrm{ml}\right.$ ) compared to standard Gallic acid $\left(\mathrm{IC}_{50} ; 102.17 \pm 0.49 \mu \mathrm{g} / \mathrm{ml}\right.$ ) (Tables 6 and 7 ).

\section{Hydroxyl radical scavenging activity}

In this experiment, leaf and bark aqueous crude extracts $\left(\mathrm{IC}_{50}\right.$; leaf aqueous: $566.80 \pm 2.02 \mu \mathrm{g} / \mathrm{ml}$, bark aqueous: $458.45 \pm 2.29 \mu \mathrm{g} / \mathrm{ml}$ ) were shown appreciable radical scavenging activity but leaf and bark ethanolic crude extracts $\left(\mathrm{IC}_{50}\right.$; leaf ethanol: $396.44 \pm 2.87 \mu \mathrm{g} / \mathrm{ml}$, bark ethanol: $286.88 \pm 2.41 \mu \mathrm{g} / \mathrm{ml}$ ) shows excellent results compare to the rest of the extracts. The pure compound "benzene ethanol, 4-hydroxy-alcohol" shows excellent activity ( $\mathrm{IC}_{50} ; 181.90 \pm 0.59 \mu \mathrm{g} / \mathrm{ml}$ ) higher than the standard gallic acid $\left(\mathrm{IC}_{50} ; 200.51 \pm 2.45 \mu \mathrm{g} / \mathrm{ml}\right)$ used (Tables 7 and 8). 
Table 1: DPPH Radical Scavenging activity of various extracts of Olea dioica

\begin{tabular}{|c|c|c|c|c|c|c|c|c|}
\hline S No. & Activity & $\begin{array}{l}\text { Plant } \\
\text { part }\end{array}$ & Extracts & Concentration in $\mu \mathrm{g} / \mathrm{ml}$ & $\begin{array}{l}\text { Scavenging } \\
\text { activity }\end{array}$ & IC $_{50}$ value & $\begin{array}{l}\text { Standard } \mu \mathrm{g} / \mathrm{ml} \\
\text { (ascorbic acid) }\end{array}$ & $\begin{array}{l}\mathrm{IC}_{50} \text { value } \\
\text { of standard } \\
\text { ascorbic acid }\end{array}$ \\
\hline \multirow[t]{14}{*}{1} & $\begin{array}{l}\text { DPPH radical } \\
\text { scavenging } \\
\text { activity }\end{array}$ & Leaf & Aqueous & 25 & $49.27 \pm 0.20$ & $90.96 \pm 0.21$ & $76.23 \pm 0.23$ & $39.48 \pm 0.02$ \\
\hline & & & & 50 & $50.67 \pm 0.10$ & & $82.32 \pm 0.43$ & \\
\hline & & & & 75 & $55.54 \pm 0.15$ & & $113.11 \pm 0.09$ & \\
\hline & & & & 125 & $64.43 \pm 0.66$ & & $156.43 \pm 0.02$ & \\
\hline & & & & 150 & $68.56 \pm 0.06$ & & $176.65 \pm 0.34$ & \\
\hline & & & & 175 & $71.11 \pm 0.05$ & & $189.41 \pm 0.54$ & \\
\hline & & & & 200 & $74.43 \pm 0.21$ & & $210.87 \pm 0.32$ & \\
\hline & & & Ethanol & 25 & $75.87 \pm 0.20$ & $69.12 \pm 0.30$ & $76.23 \pm 0.23$ & \\
\hline & & & & 50 & $77.11 \pm 0.05$ & & $82.32 \pm 0.43$ & \\
\hline & & & & 75 & $79.22 \pm 0.20$ & & $113.11 \pm 0.09$ & \\
\hline & & & & 100 & $80.71 \pm 0.10$ & & $134.54 \pm 0.91$ & \\
\hline & & & & 150 & $85.42 \pm 0.06$ & & $176.65 \pm 0.34$ & \\
\hline & & & & 175 & $83.22 \pm 0.20$ & & $189.41 \pm 0.54$ & \\
\hline & & & & 200 & $87.35 \pm 0.06$ & & $210.87 \pm 0.32$ & \\
\hline \multirow[t]{14}{*}{2} & & Bark & Aqueous & 25 & $38.66 \pm 0.66$ & $107.14 \pm 1.48$ & $76.23 \pm 0.23$ & \\
\hline & & & & 50 & $41.66 \pm 0.03$ & & $82.32 \pm 0.43$ & \\
\hline & & & & 75 & $45.54 \pm 0.05$ & & $113.11 \pm 0.09$ & \\
\hline & & & & 100 & $50.20 \pm 0.65$ & & $134.54 \pm 0.91$ & \\
\hline & & & & 125 & $54.50 \pm 0.10$ & & $156.43 \pm 0.02$ & \\
\hline & & & & 150 & $60.66 \pm 0.66$ & & $176.65 \pm 0.34$ & \\
\hline & & & & 175 & $62.34 \pm 0.35$ & & $189.41 \pm 0.54$ & \\
\hline & & & & 200 & $65.54 \pm 0.54$ & & $210.87 \pm 0.32$ & \\
\hline & & & Ethanol & 25 & $79.87 \pm 0.20$ & $63.77 \pm 0.39$ & $76.23 \pm 0.23$ & \\
\hline & & & & 50 & $80.11 \pm 0.05$ & & $82.32 \pm 0.43$ & \\
\hline & & & & 75 & $83.22 \pm 0.20$ & & $113.11 \pm 0.09$ & \\
\hline & & & & 100 & $86.71 \pm 0.10$ & & $134.54 \pm 0.91$ & \\
\hline & & & & 125 & $91.30 \pm 0.05$ & & $156.43 \pm 0.02$ & \\
\hline & & & & 150 & $92.42 \pm 0.05$ & & $176.65 \pm 0.34$ & \\
\hline
\end{tabular}

$\mathrm{IC}_{50}$ value is the amount of extract needed for scavenging $50 \%$ of the radical produced in the reaction mixture. Values are mean \pm standard deviation of three independent replicates. DPPH: 2,2-diphenyl-2-picrylhydrazyl

Table 2: DPPH and ABTS assay of pure compound “benzene ethanol, 4-hydroxy-alcohol" extracted form Olea dioica

\begin{tabular}{|c|c|c|c|c|c|c|c|}
\hline S. No. & Test sample & Activity & Concentration in $\mu \mathrm{g} / \mathrm{ml}$ & $\begin{array}{l}\text { Scavenging } \\
\text { activity }\end{array}$ & $\mathrm{IC}_{50}$ value & $\begin{array}{l}\text { Standard } \\
\text { ascorbic } \\
\text { acid } \mu \mathrm{g} / \mathrm{ml}\end{array}$ & $\begin{array}{l}\mathrm{IC}_{50} \text { value } \\
\text { of standard } \\
\text { ascorbic } \\
\text { acid }\end{array}$ \\
\hline \multirow[t]{7}{*}{1} & $\begin{array}{l}\text { "Benzene ethanol, } \\
\text { 4-hydroxy-alcohol" }\end{array}$ & $\begin{array}{l}\text { DPPH radical } \\
\text { scavenging activity }\end{array}$ & 25 & $77.53 \pm 0.43$ & $32.99 \pm 0.20$ & $76.23 \pm 0.23$ & $39.48 \pm 0.02$ \\
\hline & & & 50 & $99.67 \pm 0.33$ & & $82.32 \pm 0.43$ & \\
\hline & & & 75 & $140.54 \pm 0.39$ & & $113.11 \pm 0.09$ & \\
\hline & & & 125 & $187.43 \pm 0.76$ & & $156.43 \pm 0.02$ & \\
\hline & & & 150 & $210.56 \pm 0.35$ & & $176.65 \pm 0.34$ & \\
\hline & & & 175 & $234.27 \pm 0.55$ & & $189.41 \pm 0.54$ & \\
\hline & & & 200 & $254.43 \pm 0.12$ & & $210.87 \pm 0.32$ & \\
\hline \multirow[t]{7}{*}{2} & & $\begin{array}{l}\text { ABTS radical } \\
\text { scavenging activity }\end{array}$ & 50 & $54.23 \pm 0.45$ & $60.38 \pm 0.34$ & $47.34 \pm 0.32$ & $66.92 \pm 0.36$ \\
\hline & & & 100 & $98.43 \pm 0.11$ & & $84.65 \pm 0.05$ & \\
\hline & & & 150 & $136.23 \pm 0.24$ & & $120.43 \pm 0.36$ & \\
\hline & & & 250 & $194.91 \pm 0.92$ & & $185.65 \pm 0.3$ & \\
\hline & & & 300 & $243.43 \pm 0.12$ & & $214.76 \pm 0.62$ & \\
\hline & & & 350 & $287.33 \pm 0.41$ & & $254.36 \pm 0.06$ & \\
\hline & & & 400 & $310.87 \pm 0.15$ & & $287.98 \pm 0.6$ & \\
\hline
\end{tabular}

$\mathrm{IC}_{50}$ value is the amount of extract needed for scavenging $50 \%$ of the radical produced in the reaction mixture. Values are mean \pm standard deviation of three independent replicates. DPPH: 2,2-diphenyl-2-picrylhydrazyl, ABTS: 2,2-azino-bis (3-ethylbenzothiazoline)-6-sulfonic acid

In vitro cytotoxic properties

Experiment was conducting using DLA and EAC cells, reveled excellent cytotoxicity of bark extract against DLA and EAC cells. Cytotoxicity of two different crude extracts, namely, ethanolic, aqueous extracted form from leaf and bark of $O$. dioica showed dose-dependent toxicity. Toxicity of ethanolic extract was higher when compared to the aqueous extract. 
Table 3: ABTS radical scavenging activity of various extracts of Olea dioica

\begin{tabular}{|c|c|c|c|c|c|c|c|c|}
\hline S No. & Activity & $\begin{array}{l}\text { Plant } \\
\text { part }\end{array}$ & Extracts & Concentration in $\mu \mathrm{g} / \mathrm{ml}$ & $\begin{array}{l}\text { Scavenging } \\
\text { activity }\end{array}$ & $\mathrm{IC}_{50}$ value & $\begin{array}{l}\text { Standard } \mu \mathrm{g} / \mathrm{ml} \\
\text { (butylated hydroxyl } \\
\text { anisole) }\end{array}$ & $\begin{array}{l}\mathrm{IC}_{50} \\
\text { value of } \\
\text { standard } \\
\text { butylated } \\
\text { hydroxyl } \\
\text { anisole }\end{array}$ \\
\hline \multirow[t]{3}{*}{1} & $\begin{array}{l}\text { ABTS radical } \\
\text { scavenging } \\
\text { activity }\end{array}$ & Leaf & Aqueous & 50 & $7.43 \pm 0.03$ & $353.88 \pm 2.82$ & $47.34 \pm 0.32$ & $66.92 \pm 0.36$ \\
\hline & & & & $\begin{array}{l}100 \\
150 \\
200 \\
250 \\
300 \\
350 \\
400\end{array}$ & $\begin{array}{l}13.73 \pm 0.2 \\
20.56 \pm 0.66 \\
27.53 \pm 0.05 \\
36.24 \pm 0.61 \\
40.82 \pm 0.4 \\
49.43 \pm 0.05 \\
58.58 \pm 0.82\end{array}$ & & $\begin{array}{l}84.65 \pm 0.05 \\
120.43 \pm 0.36 \\
149.68 \pm 0.1 \\
185.65 \pm 0.3 \\
214.76 \pm 0.62 \\
254.36 \pm 0.06 \\
287.98 \pm 0.6\end{array}$ & \\
\hline & & & Ethanol & $\begin{array}{l}50 \\
100 \\
150 \\
200 \\
250 \\
300 \\
350 \\
400\end{array}$ & $\begin{array}{l}22.48 \pm 0.14 \\
32.92 \pm 0.36 \\
49.87 \pm 0.06 \\
57.43 \pm 0.32 \\
62.83 \pm 0.1 \\
70.49 \pm 0.62 \\
87.01 \pm 0.06 \\
95.32 \pm 0.05\end{array}$ & $188.14 \pm 1.71$ & $\begin{array}{l}47.34 \pm 0.32 \\
84.65 \pm 0.05 \\
120.43 \pm 0.36 \\
149.68 \pm 0.1 \\
185.65 \pm 0.3 \\
214.76 \pm 0.62 \\
254.36 \pm 0.06 \\
287.98 \pm 0.6\end{array}$ & \\
\hline 2 & & Bark & Aqueous & $\begin{array}{l}50 \\
100 \\
150 \\
200 \\
250 \\
300 \\
350 \\
400 \\
50 \\
100 \\
150 \\
200 \\
250 \\
300 \\
350 \\
400\end{array}$ & $\begin{array}{l}11.93 \pm 0.17 \\
23.34 \pm 0.1 \\
41.22 \pm 0.32 \\
49.11 \pm 0.4 \\
57.91 \pm 0.34 \\
64.36 \pm 0.2 \\
72.54 \pm 0.4 \\
86.43 \pm 0.05 \\
30.43 \pm 0.54 \\
48.54 \pm 0.12 \\
60.48 \pm 0.6 \\
79.39 \pm 0.05 \\
90.11 \pm 0.3 \\
107.28 \pm 0.45 \\
131.34 \pm 0.42 \\
147.87 \pm 0.6\end{array}$ & $221.21 \pm 1.98$ & $\begin{array}{l}47.34 \pm 0.32 \\
84.65 \pm 0.05 \\
120.43 \pm 0.36 \\
149.68 \pm 0.1 \\
185.65 \pm 0.3 \\
214.76 \pm 0.62 \\
254.36 \pm 0.06 \\
287.98 \pm 0.6 \\
47.34 \pm 0.32 \\
84.65 \pm 0.05 \\
120.43 \pm 0.36 \\
149.68 \pm 0.1 \\
185.65 \pm 0.3 \\
214.76 \pm 0.62 \\
254.36 \pm 0.06 \\
287.98 \pm 0.6\end{array}$ & \\
\hline
\end{tabular}

$\mathrm{IC}_{50}$ value is the amount of extract needed for scavenging $50 \%$ of the radical produced in the reaction mixture. Values are mean \pm standard deviation of three independent replicates. ABTS: 2,2-azino-bis (3-ethylbenzothiazoline)-6-sulfonic acid

Table 4: Metal chelating activity of various extracts of Olea dioica

\begin{tabular}{|c|c|c|c|c|c|c|c|c|}
\hline S No. & Activity & $\begin{array}{l}\text { Plant } \\
\text { part }\end{array}$ & Extracts & Concentration in $\mu \mathrm{g} / \mathrm{ml}$ & $\begin{array}{l}\text { Scavenging } \\
\text { activity }\end{array}$ & IC $_{50}$ value & Standard $\mu \mathrm{g} / \mathrm{ml}$ (EDTA) & $\begin{array}{l}\text { IC }_{50} \text { value } \\
\text { of Standard } \\
\text { EDTA }\end{array}$ \\
\hline \multirow[t]{16}{*}{1} & \multirow{16}{*}{$\begin{array}{l}\text { Metal } \\
\text { chelating } \\
\text { activity }\end{array}$} & \multirow[t]{16}{*}{ Leaf } & \multirow[t]{8}{*}{ Aqueous } & 200 & $6.4 \pm 0.1$ & \multirow[t]{8}{*}{$1639.12 \pm 2.87$} & $58.76 \pm 0.32$ & \multirow[t]{19}{*}{$213.69 \pm 0.32$} \\
\hline & & & & 400 & $11.09 \pm 0.2$ & & $98.34 \pm 0.03$ & \\
\hline & & & & 600 & $19.45 \pm 0.36$ & & $144.65 \pm 0.32$ & \\
\hline & & & & 800 & $25.53 \pm 0.32$ & & $195.76 \pm 0.45$ & \\
\hline & & & & 1000 & $31.64 \pm 0.61$ & & $242.87 \pm 0.14$ & \\
\hline & & & & 1200 & $37.24 \pm 0.4$ & & $283.24 \pm 0.36$ & \\
\hline & & & & 1400 & $43.57 \pm 0.06$ & & $332.31 \pm 0.05$ & \\
\hline & & & & 1800 & $50.81 \pm 0.82$ & & $375.52 \pm 0.82$ & \\
\hline & & & \multirow[t]{8}{*}{ Ethanol } & 200 & $29.84 \pm 0.3$ & \multirow[t]{8}{*}{$637.67 \pm 2.61$} & $58.76 \pm 0.32$ & \\
\hline & & & & 400 & $47.92 \pm 0.4$ & & $98.34 \pm 0.03$ & \\
\hline & & & & 600 & $58.47 \pm 0.6$ & & $144.65 \pm 0.32$ & \\
\hline & & & & 800 & $64.43 \pm 0.45$ & & $195.76 \pm 0.45$ & \\
\hline & & & & 1000 & $81.83 \pm 0.66$ & & $242.87 \pm 0.14$ & \\
\hline & & & & 1200 & $90.49 \pm 0.1$ & & $283.24 \pm 0.36$ & \\
\hline & & & & 1400 & $99.91 \pm 0.05$ & & $332.31 \pm 0.05$ & \\
\hline & & & & 1800 & $107.34 \pm 0.05$ & & $375.52 \pm 0.82$ & \\
\hline \multirow[t]{3}{*}{2} & & \multirow[t]{3}{*}{ Bark } & \multirow[t]{3}{*}{ Aqueous } & 200 & $9.87 \pm 0.14$ & \multirow[t]{3}{*}{$1132.19 \pm 2.15$} & $58.76 \pm 0.32$ & \\
\hline & & & & 400 & $18.23 \pm 0.03$ & & $98.34 \pm 0.03$ & \\
\hline & & & & 600 & $26.45 \pm 0.6$ & & $144.65 \pm 0.32$ & \\
\hline
\end{tabular}


Table 4: (Continued)

\begin{tabular}{|c|c|c|c|c|c|c|c|c|}
\hline S No. & Activity & $\begin{array}{l}\text { Plant } \\
\text { part }\end{array}$ & Extracts & Concentration in $\mu \mathrm{g} / \mathrm{ml}$ & $\begin{array}{l}\text { Scavenging } \\
\text { activity }\end{array}$ & IC $_{50}$ value & Standard $\mu \mathrm{g} / \mathrm{ml}$ (EDTA) & $\begin{array}{l}\mathrm{IC}_{50} \text { value } \\
\text { of Standard } \\
\text { EDTA }\end{array}$ \\
\hline & & & \multirow{12}{*}{ Ethanol } & 800 & $34.76 \pm 0.32$ & \multirow{12}{*}{$472.43 \pm 1.96$} & $195.76 \pm 0.45$ & \\
\hline & & & & 1000 & $46.47 \pm 0.54$ & & $242.87 \pm 0.14$ & \\
\hline & & & & 1200 & $54.32 \pm 0.42$ & & $283.24 \pm 0.36$ & \\
\hline & & & & 1400 & $61.38 \pm 0.05$ & & $332.31 \pm 0.05$ & \\
\hline & & & & 1800 & $75.32 \pm 0.05$ & & $375.52 \pm 0.82$ & \\
\hline & & & & 400 & $54.32 \pm 0.12$ & & $98.34 \pm 0.03$ & \\
\hline & & & & 600 & $70.28 \pm 0.06$ & & $144.65 \pm 0.32$ & \\
\hline & & & & 800 & $91.93 \pm 0.62$ & & $195.76 \pm 0.45$ & \\
\hline & & & & 1000 & $119.91 \pm 0.34$ & & $242.87 \pm 0.14$ & \\
\hline & & & & 1200 & $125.31 \pm 0.2$ & & $283.24 \pm 0.36$ & \\
\hline & & & & 1400 & $135.95 \pm 0.4$ & & $332.31 \pm 0.05$ & \\
\hline & & & & 1800 & $149.11 \pm 0.05$ & & $375.52 \pm 0.82$ & \\
\hline
\end{tabular}

$\mathrm{IC}_{50}$ value is the amount of extract needed for scavenging $50 \%$ of the radical produced in the reaction mixture. Values are mean \pm standard deviation of three independent replicates

Table 5: Metal chelating assay of pure compound "benzene-ethanol, 4-hydroxy-alcohol" of Olea dioica

\begin{tabular}{|c|c|c|c|c|c|c|c|}
\hline S. No. & Test sample & Activity & Concentration in $\mu \mathrm{g} / \mathrm{ml}$ & $\begin{array}{l}\text { Scavenging } \\
\text { activity }\end{array}$ & IC $_{50}$ value & Standard $\mu \mathrm{g} / \mathrm{ml}$ (EDTA) & $\begin{array}{l}\mathrm{IC}_{50} \text { value } \\
\text { of standard } \\
\text { EDTA }\end{array}$ \\
\hline \multirow[t]{7}{*}{1} & $\begin{array}{l}\text { "Benzene ethanol, } \\
\text { 4-hydroxy-alcohol" }\end{array}$ & $\begin{array}{l}\text { Metal } \\
\text { chelating } \\
\text { assay }\end{array}$ & 200 & $59.99 \pm 0.22$ & $201.52 \pm 2.43$ & $58.76 \pm 0.32$ & $213.69 \pm 0.32$ \\
\hline & & & 400 & $111.33 \pm 0.14$ & & $98.34 \pm 0.03$ & \\
\hline & & & 600 & $152.65 \pm 0.55$ & & $144.65 \pm 0.32$ & \\
\hline & & & 1000 & $253.77 \pm 0.76$ & & $242.87 \pm 0.14$ & \\
\hline & & & 1200 & $302.50 \pm 0.50$ & & $283.24 \pm 0.36$ & \\
\hline & & & 1400 & $354.21 \pm 0.76$ & & $332.31 \pm 0.05$ & \\
\hline & & & 1800 & $400.14 \pm 0.34$ & & $375.52 \pm 0.82$ & \\
\hline
\end{tabular}

$\mathrm{IC}_{50}$ value is the amount of extract needed for scavenging $50 \%$ of the radical produced in the reaction mixture. Values are mean \pm standard deviation of three independent replicates

Table 6: Superoxide radicals scavenging NBT reduction method of various extracts of Olea dioica

\begin{tabular}{|c|c|c|c|c|c|c|c|c|}
\hline S No. & Activity & $\begin{array}{l}\text { Plant } \\
\text { part }\end{array}$ & Extracts & $\begin{array}{l}\text { Concentration } \\
\text { in } \mu \mathrm{g} / \mathrm{ml}\end{array}$ & $\begin{array}{l}\text { Scavenging } \\
\text { activity }\end{array}$ & IC $_{50}$ value & $\begin{array}{l}\text { Standard gallic } \\
\text { acid } \mu \mathrm{g} / \mathrm{ml}\end{array}$ & $\begin{array}{l}\mathrm{IC}_{50} \text { value } \\
\text { standard } \\
\text { gallic acid }\end{array}$ \\
\hline \multirow[t]{14}{*}{1} & \multirow[t]{22}{*}{$\begin{array}{l}\text { Superoxide radicals } \\
\text { scavenging NBT } \\
\text { reduction method }\end{array}$} & \multirow[t]{14}{*}{ Leaf } & \multirow[t]{7}{*}{ Aqueous } & 100 & $14.76 \pm 0.06$ & \multirow[t]{7}{*}{$344.97 \pm 2.77$} & $51.66 \pm 0.11$ & \multirow[t]{22}{*}{$102.17 \pm 0.49$} \\
\hline & & & & 200 & $23.53 \pm 0.17$ & & $95.67 \pm 0.54$ & \\
\hline & & & & 300 & $55.54 \pm 0.62$ & & $148.12 \pm 0.42$ & \\
\hline & & & & 500 & $75.43 \pm 0.54$ & & $247.32 \pm 0.49$ & \\
\hline & & & & 600 & $82.43 \pm 0.06$ & & $282.22 \pm 0.19$ & \\
\hline & & & & 700 & $96.72 \pm 0.05$ & & $341.21 \pm 0.24$ & \\
\hline & & & & 800 & $103.71 \pm 0.61$ & & $395.74 \pm 0.63$ & \\
\hline & & & \multirow{7}{*}{ Ethanol } & 100 & $24.65 \pm 0.6$ & \multirow{7}{*}{$262.14 \pm 3.18$} & $51.66 \pm 0.11$ & \\
\hline & & & & 200 & $48.09 \pm 0.4$ & & $95.67 \pm 0.54$ & \\
\hline & & & & 300 & $64.76 \pm 0.3$ & & $148.12 \pm 0.42$ & \\
\hline & & & & 400 & $80.71 \pm 0.6$ & & $199.77 \pm 1.34$ & \\
\hline & & & & 600 & $110.43 \pm 0.12$ & & $282.22 \pm 0.19$ & \\
\hline & & & & 700 & $122.54 \pm 0.4$ & & $341.21 \pm 0.24$ & \\
\hline & & & & 800 & $136.34 \pm 0.34$ & & $395.74 \pm 0.63$ & \\
\hline \multirow[t]{8}{*}{2} & & \multirow[t]{8}{*}{ Bark } & \multirow[t]{8}{*}{ Aqueous } & 100 & $22.65 \pm 0.32$ & \multirow[t]{8}{*}{$299.38 \pm 2.49$} & $51.66 \pm 0.11$ & \\
\hline & & & & 200 & $41.66 \pm 0.03$ & & $95.67 \pm 0.54$ & \\
\hline & & & & 300 & $59.02 \pm 0.32$ & & $148.12 \pm 0.42$ & \\
\hline & & & & 400 & $71.27 \pm 0.45$ & & $199.77 \pm 1.34$ & \\
\hline & & & & 500 & $86.54 \pm 0.14$ & & $247.32 \pm 0.49$ & \\
\hline & & & & 600 & $99.87 \pm 0.36$ & & $282.22 \pm 0.19$ & \\
\hline & & & & 700 & $105.65 \pm 0.05$ & & $341.21 \pm 0.24$ & \\
\hline & & & & 800 & $114.58 \pm 0.82$ & & $395.74 \pm 0.63$ & \\
\hline
\end{tabular}


Table 6: (Continued)

\begin{tabular}{|c|c|c|c|c|c|c|c|c|}
\hline S No. & Activity & $\begin{array}{l}\text { Plant } \\
\text { part }\end{array}$ & Extracts & $\begin{array}{l}\text { Concentration } \\
\text { in } \mu \mathrm{g} / \mathrm{ml}\end{array}$ & $\begin{array}{l}\text { Scavenging } \\
\text { activity }\end{array}$ & IC $_{50}$ value & $\begin{array}{l}\text { Standard gallic } \\
\text { acid } \mu \mathrm{g} / \mathrm{ml}\end{array}$ & $\begin{array}{l}\mathrm{IC}_{50} \text { value } \\
\text { standard } \\
\text { gallic acid }\end{array}$ \\
\hline & & & Ethanol & $\begin{array}{l}100 \\
200 \\
300 \\
400 \\
500 \\
600 \\
700 \\
800\end{array}$ & $\begin{array}{l}30.45 \pm 0.2 \\
49.56 \pm 0.05 \\
68.61 \pm 0.2 \\
86.71 \pm 0.1 \\
100.1 \pm 0.05 \\
124.13 \pm 0.05 \\
148.43 \pm 0.1 \\
165.33 \pm 0.4\end{array}$ & $232.76 \pm 1.15$ & $\begin{array}{l}51.66 \pm 0.11 \\
95.67 \pm 0.54 \\
148.12 \pm 0.42 \\
199.77 \pm 1.34 \\
247.32 \pm 0.49 \\
282.22 \pm 0.19 \\
341.21 \pm 0.24 \\
395.74 \pm 0.63\end{array}$ & \\
\hline
\end{tabular}

$\mathrm{IC}_{50}$ value is the amount of extract needed for scavenging $50 \%$ of the radical produced in the reaction mixture. Values are mean \pm standard deviation of three independent replicates. NBT: Nitro blue tetrazolium

Table 7: NBT and hydroxyl radical scavenging assay of pure compound "benzene-ethanol, 4-hydroxy- alcohol" of Olea dioica

\begin{tabular}{|c|c|c|c|c|c|c|c|}
\hline S. No. & Test sample & Activity & $\begin{array}{l}\text { Concentration } \\
\text { in } \mu \mathrm{g} / \mathrm{ml}\end{array}$ & $\begin{array}{l}\text { Scavenging } \\
\text { activity }\end{array}$ & IC $_{50}$ value & $\begin{array}{l}\text { Standard gallic } \\
\text { acid } \mu \mathrm{g} / \mathrm{ml}\end{array}$ & $\begin{array}{l}\text { IC }_{50} \text { value } \\
\text { of standard } \\
\text { gallic acid }\end{array}$ \\
\hline \multirow[t]{9}{*}{1} & $\begin{array}{l}\text { "Benzene ethanol, } \\
\text { 4-hydroxy-alcohol" }\end{array}$ & $\begin{array}{l}\text { Superoxide } \\
\text { radicals } \\
\text { scavenging } \\
\text { NBT reduction } \\
\text { method }\end{array}$ & 100 & $51.53 \pm 0.34$ & $99.92 \pm 0.54$ & $51.66 \pm 0.11$ & $102.17 \pm 0.49$ \\
\hline & & & 200 & $100.64 \pm 0.45$ & & $95.67 \pm 0.54$ & \\
\hline & & & 300 & $153.53 \pm 0.11$ & & $148.12 \pm 0.42$ & \\
\hline & & & 400 & $200.34 \pm 0.98$ & & $199.77 \pm 1.34$ & \\
\hline & & & 500 & $253.65 \pm 0.35$ & & $247.32 \pm 0.49$ & \\
\hline & & & 600 & $291.16 \pm 0.05$ & & $282.22 \pm 0.19$ & \\
\hline & & & 700 & $351.22 \pm 0.27$ & & $341.21 \pm 0.24$ & \\
\hline & & & 800 & $399.23 \pm 0.76$ & & $395.74 \pm 0.63$ & \\
\hline & & & $\begin{array}{l}\text { Concentration } \\
\text { in } \mu \mathrm{g} / \mathrm{ml}\end{array}$ & $\begin{array}{l}\text { Scavenging } \\
\text { activity }\end{array}$ & $\mathrm{IC}_{50}$ value & $\begin{array}{l}\text { Standard } \mu \mathrm{g} / \mathrm{ml} \\
\text { (EDTA) }\end{array}$ & $\begin{array}{l}\mathrm{IC}_{50} \text { value } \\
\text { of standard } \\
\text { EDTA }\end{array}$ \\
\hline \multirow[t]{8}{*}{2} & & $\begin{array}{l}\text { Hydroxyl radical } \\
\text { scavenging } \\
\text { assay }\end{array}$ & 100 & $35.23 \pm 0.42$ & $181.90 \pm 0.59$ & $32.14 \pm 0.63$ & $200.51 \pm 2.45$ \\
\hline & & & 200 & $66.43 \pm 0.19$ & & $58.76 \pm 0.32$ & \\
\hline & & & 300 & $96.23 \pm 0.63$ & & $76.58 \pm 0.98$ & \\
\hline & & & 400 & $123.12 \pm 0.98$ & & $98.34 \pm 0.03$ & \\
\hline & & & 500 & $124.91 \pm 0.03$ & & $119.24 \pm 0.19$ & \\
\hline & & & 600 & $150.43 \pm 0.27$ & & $144.65 \pm 0.31$ & \\
\hline & & & 700 & $182.33 \pm 0.76$ & & $172.23 \pm 0.48$ & \\
\hline & & & 800 & $210.87 \pm 0.03$ & & $195.76 \pm 0.45$ & \\
\hline
\end{tabular}

$\mathrm{IC}_{50}$ value is the amount of extract needed for scavenging $50 \%$ of the radical produced in the reaction mixture. Values are mean \pm standard deviation of three independent replicates. NBT: Nitro blue tetrazolium

\section{Trypan blue dye exclusion technique}

In this method, two extracts (leaf ethanolic and stem ethanolic extract) were tested for its cytotoxicity, revealed that, stem ethanolic crude extract is effective against DLA (CTC ${ }_{50} 187.3 \pm 0.5 \mu \mathrm{g} / \mathrm{ml}$ ) and EAC cells (CTC $146.7 \pm 1.5 \mu \mathrm{g} / \mathrm{ml}$ ) when compared to leaf ethanolic extractagainst DLA (CTC ${ }_{50:} 266.1 \pm 1.5 \mu \mathrm{g} / \mathrm{ml}$ ) and EAC cells $\left(\mathrm{CTC}_{50:} 184.1 \pm 1.2 \mu \mathrm{g} / \mathrm{ml}\right)$. The pure compound "Benzene ethanol, 4-hydroxy- alcohol" showed excellent cytotoxic activity for both DLA $\left(\mathrm{CTC}_{50} 62.91 \pm 1.5 \mu \mathrm{g} / \mathrm{ml}\right)$ and EAC cells $\left(\mathrm{CTC}_{50} 63.86 \pm 2.5 \mu \mathrm{g} / \mathrm{ml}\right)$ which is comparable to the standard curcumin $\left(\right.$ CTC $_{50:} 54.31 \pm 1.5 \mu \mathrm{g} / \mathrm{ml}$ ) (Tables 9 and 10).

\section{MTT assay}

All the two extracts (leaf ethanolic and stem ethanolic extract) were tested for its cytotoxicity, in that bark ethanolic crude extract showed excellent cytotoxicity against DLA $\left(\mathrm{CTC}_{50:} 191.33 \pm 1.5 \mu \mathrm{g} / \mathrm{ml}\right)$ and EAC $\left(\mathrm{CTC}_{50}: 132.96 \pm 0.5 \mu \mathrm{g} / \mathrm{ml}\right)$ cells compared to leaf ethanolic crude extract against DLA $\left(\mathrm{CTC}_{50:} 260.63 \pm 0.5 \mu \mathrm{g} / \mathrm{ml}\right)$ and $\mathrm{EAC}$ $\left(\mathrm{CTC}_{50}, 194.27 \pm 2.5 \mu \mathrm{g} / \mathrm{ml}\right)$. The pure compound "Benzene ethanol, 4-hydroxy- alcohol" extracted form stem ethanolic crude extract showed excellent cytotoxic activity DLA ( $\left.\mathrm{CTC}_{50:} 62.45 \pm 0.5 \mu \mathrm{g} / \mathrm{ml}\right)$ and EAC cells $\left(\mathrm{CTC}_{50} 62.31 \pm 3.4 \mu \mathrm{g} / \mathrm{ml}\right)$ which is almost comparable to the standard curcumin $\left(\mathrm{CTC}_{50:} 54.31 \pm 1.5 \mu \mathrm{g} / \mathrm{ml}\right.$ ) (Tables 11 and 12 ).

\section{CONCLUSION}

The present study shows that the both leaf and bark ethanolic crude extracts have remarkable antioxidant and cytotoxic properties compared to both leaf and bark aqueous extracts. The pure compound "benzene ethanol, 4-hydroxy-alcohol" extracted form bark methanolic crude extract has excellent antioxidant and cytotoxic which is almost equal to the standards used. These results confirm positive activity of the plant as therapeutic agent in tribal siddha medicine. Thus, $O$. dioica bark could be exploited as a valuable source of antioxidant and cytotoxic agent for pharmaceutical industry.

\section{AKNOWLEDGMENT}

We are thankful to Prof. Ramadasa Kuttan, Director, Amala Cancer Research Centre, Trissur. Kerala, for providing facilities to conduct our experimental work and Department of PG studies and Research in 
Table 8: Hydroxyl radical scavenging assay of various extracts of Olea dioica

\begin{tabular}{|c|c|c|c|c|c|c|c|c|}
\hline S No. & Activity & $\begin{array}{l}\text { Plant } \\
\text { part }\end{array}$ & Extracts & $\begin{array}{l}\text { Concentration } \\
\text { in } \mu \mathrm{g} / \mathrm{ml}\end{array}$ & $\begin{array}{l}\text { Scavenging } \\
\text { activity }\end{array}$ & IC $_{50}$ value & Standard $\mu \mathrm{g} / \mathrm{ml}$ (EDTA) & $\begin{array}{l}\text { IC }_{50} \text { value } \\
\text { standard } \\
\text { EDTA }\end{array}$ \\
\hline \multirow[t]{16}{*}{1} & \multirow{32}{*}{$\begin{array}{l}\text { Hydroxyl radical } \\
\text { scavenging } \\
\text { assay }\end{array}$} & \multirow[t]{16}{*}{ Leaf } & \multirow[t]{8}{*}{ Aqueous } & 100 & $9.43 \pm 0.06$ & \multirow[t]{8}{*}{$566.80 \pm 2.02$} & $32.14 \pm 0.63$ & \multirow[t]{32}{*}{$200.51 \pm 2.45$} \\
\hline & & & & 200 & $15.61 \pm 0.12$ & & $58.76 \pm 0.32$ & \\
\hline & & & & 300 & $25.43 \pm 0.32$ & & $76.58 \pm 0.98$ & \\
\hline & & & & 400 & $32.48 \pm 0.05$ & & $98.34 \pm 0.03$ & \\
\hline & & & & 500 & $41.98 \pm 0.42$ & & $119.24 \pm 0.19$ & \\
\hline & & & & 600 & $52.45 \pm 0.6$ & & $144.65 \pm 0.31$ & \\
\hline & & & & 700 & $60.43 \pm 0.4$ & & $172.23 \pm 0.48$ & \\
\hline & & & & 800 & $79.76 \pm 0.05$ & & $195.76 \pm 0.45$ & \\
\hline & & & \multirow[t]{8}{*}{ Ethanol } & 100 & $19.08 \pm 0.03$ & \multirow[t]{8}{*}{$396.44 \pm 2.87$} & $32.14 \pm 0.63$ & \\
\hline & & & & 200 & $24.56 \pm 0.2$ & & $58.76 \pm 0.32$ & \\
\hline & & & & 300 & $39.34 \pm 0.66$ & & $76.58 \pm 0.98$ & \\
\hline & & & & 400 & $50.32 \pm 0.17$ & & $98.34 \pm 0.03$ & \\
\hline & & & & 500 & $62.45 \pm 0.54$ & & $119.24 \pm 0.19$ & \\
\hline & & & & 600 & $78.32 \pm 0.4$ & & $144.65 \pm 0.31$ & \\
\hline & & & & 700 & $89.65 \pm 0.05$ & & $172.23 \pm 0.48$ & \\
\hline & & & & 800 & $90.32 \pm 0.82$ & & $195.76 \pm 0.45$ & \\
\hline \multirow[t]{16}{*}{2} & & \multirow[t]{16}{*}{ Bark } & \multirow[t]{8}{*}{ Aqueous } & 100 & $10.53 \pm 0.45$ & \multirow[t]{8}{*}{$458.45 \pm 2.29$} & $32.14 \pm 0.63$ & \\
\hline & & & & 200 & $21.21 \pm 0.14$ & & $58.76 \pm 0.32$ & \\
\hline & & & & 300 & $34.22 \pm 0.2$ & & $76.58 \pm 0.98$ & \\
\hline & & & & 400 & $43.11 \pm 0.05$ & & $98.34 \pm 0.03$ & \\
\hline & & & & 500 & $54.91 \pm 0.1$ & & $119.24 \pm 0.19$ & \\
\hline & & & & 600 & $67.36 \pm 0.4$ & & $144.65 \pm 0.31$ & \\
\hline & & & & 700 & $74.54 \pm 0.61$ & & $172.23 \pm 0.48$ & \\
\hline & & & & 800 & $86.74 \pm 0.34$ & & $195.76 \pm 0.45$ & \\
\hline & & & \multirow[t]{8}{*}{ Ethanol } & 100 & $25.43 \pm 0.32$ & \multirow[t]{8}{*}{$286.88 \pm 2.41$} & $32.14 \pm 0.63$ & \\
\hline & & & & 200 & $39.54 \pm 0.05$ & & $58.76 \pm 0.32$ & \\
\hline & & & & 300 & $52.48 \pm 0.36$ & & $76.58 \pm 0.98$ & \\
\hline & & & & 400 & $71.39 \pm 0.1$ & & $98.34 \pm 0.03$ & \\
\hline & & & & 500 & $89.11 \pm 0.3$ & & $119.24 \pm 0.19$ & \\
\hline & & & & 600 & $100.28 \pm 0.62$ & & $144.65 \pm 0.31$ & \\
\hline & & & & 700 & $118.34 \pm 0.06$ & & $172.23 \pm 0.48$ & \\
\hline & & & & 800 & $130.87 \pm 0.6$ & & $195.76 \pm 0.45$ & \\
\hline
\end{tabular}

$\mathrm{IC}_{50}$ value is the amount of extract needed for scavenging $50 \%$ of the radical produced in the reaction mixture. Values are mean \pm standard deviation of three independent replicates

Table 9: In vitro cytotoxic screening by Olea dioica leaf and bark ethanolic extracts against DLA and EAC cells by trypan blue dye exclusion technique

\begin{tabular}{|c|c|c|c|c|c|c|c|c|c|c|c|}
\hline \multirow[t]{3}{*}{ S. No. } & \multirow{3}{*}{$\begin{array}{l}\text { Concentration } \\
(\mu \mathrm{g} / \mathrm{ml})\end{array}$} & \multicolumn{4}{|l|}{ DLA cells } & \multicolumn{4}{|l|}{ EAC cells } & \multirow{3}{*}{$\begin{array}{l}\text { Standard } \\
\text { (curcumin) }\end{array}$} & \multirow[t]{3}{*}{ Control } \\
\hline & & \multicolumn{2}{|l|}{ Leaf extract } & \multicolumn{2}{|l|}{ Bark extract } & \multicolumn{2}{|l|}{ Leaf extract } & \multicolumn{2}{|l|}{ Bark extract } & & \\
\hline & & $\begin{array}{l}\text { Percentage } \\
\text { cytotoxicity }\end{array}$ & $\mathrm{CTC}_{50}$ & $\begin{array}{l}\text { Percentage } \\
\text { cytotoxicity }\end{array}$ & $\mathrm{CTC}_{50}$ & $\begin{array}{l}\text { Percentage } \\
\text { cytotoxicity }\end{array}$ & $\mathrm{CTC}_{50}$ & $\begin{array}{l}\text { Percentage } \\
\text { cytotoxicity }\end{array}$ & $\mathrm{CTC}_{50}$ & & \\
\hline 1 & 10 & $0.6 \pm 0.5$ & $266.1 \pm 1.5$ & $0.6 \pm 0.5$ & $187.3 \pm 0.5$ & $1 \pm 1$ & $184.1 \pm 1.2$ & $5 \pm 1$ & $146.7 \pm 1.5$ & $15.4 \pm 3.3$ & $0.23 \pm 1.54$ \\
\hline 2 & 20 & $8.6 \pm 1.5$ & & $7.3 \pm 2$ & & $8.6 \pm 1.5$ & & $12.6 \pm 2.5$ & & $34.4 \pm 3.3$ & \\
\hline 3 & 50 & $12.3 \pm 1.5$ & & $12.6 \pm 1.1$ & & $15 \pm 1.7$ & & $26 \pm 2$ & & $100 \pm 0.5$ & \\
\hline 5 & 200 & $32.3 \pm 1.5$ & & $49.3 \pm 1.5$ & & $46.6 \pm 2$ & & $52.3 \pm 1.5$ & & $100 \pm 0.5$ & \\
\hline
\end{tabular}

$\mathrm{CTC}_{50}$ value is the amount of extract needed for $50 \%$ cytotoxicity. Values are mean \pm standard deviation of three independent replicates. EAC: Ehrlich's ascites carcinoma, DLA: Dalton's lymphoma ascites

Table 10: Trypan blue dye exclusion technique "benzene ethanol, 4-hydroxy-alcohol" of Olea dioica

\begin{tabular}{|c|c|c|c|c|c|c|c|c|}
\hline \multirow[t]{2}{*}{ S. No. } & \multirow[t]{2}{*}{$\begin{array}{l}\text { Concentration } \\
(\mu \mathrm{g} / \mathrm{ml})\end{array}$} & \multicolumn{2}{|c|}{$\begin{array}{l}\text { Trypan blue dye } \\
\text { exclusion technique for } \\
\text { DLA cells }\end{array}$} & \multicolumn{2}{|c|}{$\begin{array}{l}\text { Trypan blue dye } \\
\text { exclusion technique for } \\
\text { EAC cells }\end{array}$} & \multirow[t]{2}{*}{ Standard (curcumin) } & \multirow[t]{2}{*}{ Standard $\mathrm{CTC}_{50}$} & \multirow[t]{2}{*}{ Control } \\
\hline & & $\begin{array}{l}\text { Percentage } \\
\text { cytotoxicity }\end{array}$ & $\mathrm{CTC}_{50}$ & $\begin{array}{l}\text { Percentage } \\
\text { cytotoxicity }\end{array}$ & $\mathrm{CTC}_{50}$ & & & \\
\hline 1 & 10 & $16.3 \pm 0.5$ & \multirow[t]{5}{*}{$62.91 \pm 1.5$} & $13.7 \pm 1.5$ & \multirow[t]{5}{*}{$63.86 \pm 2.5$} & $15.4 \pm 3.3$ & \multirow[t]{5}{*}{$54.31 \pm 1.5$} & \multirow[t]{5}{*}{$0.23 \pm 1.54$} \\
\hline 2 & 20 & $31.2 \pm 1.5$ & & $26.4 \pm 2.3$ & & $34.4 \pm 3.3$ & & \\
\hline 3 & 50 & $54.5 .2 \pm 0.5$ & & $57.4 \pm 1.2$ & & $100 \pm 0.5$ & & \\
\hline 4 & 100 & $100 \pm 2.5$ & & $100 \pm 2.3$ & & $100 \pm 0.5$ & & \\
\hline 5 & 200 & $100 \pm 1.5$ & & $100 \pm 2.3$ & & $100 \pm 0.5$ & & \\
\hline
\end{tabular}

$\mathrm{CTC}_{50}$ value is the amount of extract needed for $50 \%$ cytotoxicity. Values are mean \pm standard deviation of three independent replicates. EAC: Ehrlich's ascites carcinoma, DLA: Dalton's lymphoma ascites 
Table 11: In vitro cytotoxic screening by Olea dioica leaf and bark ethanolic extracts against DLA and EAC cells by MTT assay

\begin{tabular}{|c|c|c|c|c|c|c|c|c|c|c|}
\hline \multirow[t]{3}{*}{ S. No. } & \multirow{3}{*}{$\begin{array}{l}\text { Concentration } \\
(\mu \mathrm{g} / \mathrm{ml})\end{array}$} & \multicolumn{6}{|l|}{ DLA cells } & \multirow{3}{*}{$\begin{array}{l}\text { Absorbance } \\
\text { of standard } \\
\text { curcumin at } \\
570 \mathrm{~nm}\end{array}$} & \multirow{3}{*}{$\begin{array}{l}\text { Standard } \\
\text { (curcumin) \% } \\
\text { cytotoxicity }\end{array}$} & \multirow[t]{3}{*}{ Control } \\
\hline & & \multicolumn{3}{|l|}{ Leaf extract } & \multicolumn{3}{|l|}{ Bark extract } & & & \\
\hline & & $\begin{array}{l}\text { Absorbance } \\
\text { at } 570 \mathrm{~nm}\end{array}$ & $\begin{array}{l}\text { Percentage } \\
\text { cytotoxicity }\end{array}$ & $\mathrm{CTC}_{50}$ & $\begin{array}{l}\text { Absorbance } \\
\text { at } 570 \mathrm{~nm}\end{array}$ & $\begin{array}{l}\text { Percentage } \\
\text { cytotoxicity }\end{array}$ & $\mathrm{CTC}_{50}$ & & & \\
\hline & DLA cells & & & & & & & & & \\
\hline 1 & 10 & $7.97 \pm 1.5$ & $0.3 \pm 0.5$ & $260.63 \pm 0.5$ & $7.93 \pm 1.5$ & $0.8 \pm 0.5$ & $191.33 \pm 1.5$ & $0.211 \pm 0.24$ & $15.4 \pm 3.3$ & $0.29 \pm 0.5$ \\
\hline 2 & 20 & $7.41 \pm 1.5$ & $7.3 \pm 1.5$ & & $7.44 \pm 0.5$ & $7 \pm 2$ & & $0.123 \pm 0.18$ & $34.4 \pm 3.3$ & \\
\hline 3 & 50 & $6.93 \pm 1.5$ & $13.3 \pm 2$ & & $6.99 \pm 1.2$ & $12.6 \pm 2$ & & $0.001 \pm 0.01$ & $100 \pm 0.5$ & \\
\hline 4 & 100 & $6.64 \pm 1.5$ & $17 \pm 2.6$ & & $5.57 \pm 1.5$ & $30.3 \pm 0.5$ & & $0.001 \pm 0.01$ & $100 \pm 0.5$ & \\
\hline 5 & $\begin{array}{l}200 \\
\text { EAC cells }\end{array}$ & $5.20 \pm 0.5$ & $35 \pm 1.7$ & & $4.11 \pm 0.5$ & $48.6 \pm 2$ & & $0.001 \pm 0.01$ & $100 \pm 0.5$ & \\
\hline 1 & 10 & $7.96 \pm 1.25$ & $0.5 \pm 1$ & $194.27 \pm 2.5$ & $7.89 \pm 1.2$ & $1.3 \pm 2$ & $132.96 \pm 0.5$ & $0.211 \pm 0.24$ & $15.4 \pm 3.3$ & $0.31 \pm 1.5$ \\
\hline 2 & 20 & $7.33 \pm 2.5$ & $8.3 \pm 1.5$ & & $7.09 \pm 0.5$ & $11.3 \pm 1.5$ & & $0.123 \pm 0.18$ & $34.4 \pm 3.3$ & \\
\hline 3 & 50 & $6.88 \pm 0.5$ & $14 \pm 1.7$ & & $6.07 \pm 1.5$ & $24 \pm 2$ & & $0.001 \pm 0.01$ & $100 \pm 0.5$ & \\
\hline 4 & 100 & $5.52 \pm 2.5$ & $31 \pm 2$ & & $5.36 \pm 25$ & $33 \pm 2.6$ & & $0.001 \pm 0.01$ & $100 \pm 0.5$ & \\
\hline 5 & 200 & $4.48 \pm 2.5$ & $44 \pm 2$ & & $2.15 \pm 0.5$ & $73.3 \pm 3$ & & $0.001 \pm 0.01$ & $100 \pm 0.5$ & \\
\hline
\end{tabular}

$\mathrm{CTC}_{50}$ value is the amount of extract needed for $50 \%$ cytotoxicity. Values are mean \pm standard deviation of three independent replicates. EAC: Ehrlich's ascites carcinoma, DLA: Dalton's lymphoma ascites, MTT: 3-(4, 5 dimethylthiazole-2yl)-2, 5-diphenyl tetrazolium bromide

Table 12: MTT assay of pure compound "benzene ethanol, 4-hydroxy-alcohol" of Olea dioica

\begin{tabular}{|c|c|c|c|c|c|c|c|c|c|c|c|}
\hline \multirow[t]{2}{*}{ S. No. } & \multirow{2}{*}{$\begin{array}{l}\text { Concentration } \\
(\mu \mathrm{g} / \mathrm{ml})\end{array}$} & \multicolumn{3}{|c|}{ MTT assay for DLA cells } & \multicolumn{3}{|c|}{ MTT assay for EAC cells } & \multirow{2}{*}{$\begin{array}{l}\text { Absorbance } \\
\text { of standard } \\
\text { curcumin at } \\
570 \mathrm{~nm}\end{array}$} & \multirow{2}{*}{$\begin{array}{l}\text { Standard } \\
\text { curcumin } \\
\% \\
\text { cytotoxicity }\end{array}$} & \multirow{2}{*}{$\begin{array}{l}\mathrm{CTC}_{50} \text { of } \\
\text { standard } \\
\text { (curcumin) }\end{array}$} & \multirow{2}{*}{ Control } \\
\hline & & $\begin{array}{l}\text { Absorbance } \\
\text { at } 570 \mathrm{~nm}\end{array}$ & $\begin{array}{l}\text { Percentage } \\
\text { cytotoxicity }\end{array}$ & $\mathrm{CTC}_{50}$ & $\begin{array}{l}\text { Absorbance } \\
\text { at } 570 \mathrm{~nm}\end{array}$ & $\begin{array}{l}\text { Percentage } \\
\text { cytotoxicity }\end{array}$ & $\mathrm{CTC}_{50}$ & & & & \\
\hline 1 & 10 & $6.864 \pm 1.5$ & $14.2 \pm 0.5$ & $62.45 \pm 0.5$ & $6.728 \pm 3.4$ & $15.9 \pm 1.3$ & $62.31 \pm 3.4$ & $0.211 \pm 0.24$ & $15.4 \pm 3.3$ & $54.31 \pm 1.5$ & $0.31 \pm 1.5$ \\
\hline 2 & 20 & $5.376 \pm 2.5$ & $32.8 \pm 2.5$ & & $5.608 \pm 1.3$ & $29.9 \pm 2.5$ & & $0.123 \pm 0.18$ & $34.4 \pm 3.3$ & & \\
\hline 3 & 50 & $2.744 \pm 0.5$ & $65.7 \pm 2.2$ & & $3.272 \pm 2.5$ & $59.1 \pm 1.4$ & & $0.001 \pm 0.01$ & $100 \pm 0.5$ & & \\
\hline 4 & 100 & $0.672 \pm 2.5$ & $91.6 \pm 3.4$ & & $0.001 \pm 0.01$ & $100 \pm 1.5$ & & $0.001 \pm 0.01$ & $100 \pm 0.5$ & & \\
\hline 5 & 200 & $0.001 \pm 0.01$ & $100 \pm 1.5$ & & $0.001 \pm 0.01$ & $100 \pm 1.5$ & & $0.001 \pm 0.01$ & $100 \pm 0.5$ & & \\
\hline
\end{tabular}

$\mathrm{CTC}_{50}$ value is the amount of extract needed for $50 \%$ cytotoxicity. Values are mean \pm standard deviation of three independent replicates. EAC: Ehrlich's ascites carcinoma, DLA: Dalton's lymphoma ascites, MTT: 3-(4, 5 dimethylthiazole-2yl)-2, 5-diphenyl tetrazolium bromide

Botany, Kuvempu University, Shankaraghatta, for providing laboratory facility.

\section{REFERENCES}

1. Valko M, Morris H, Cronin MT. Metals, toxicity and oxidative stress. Curr Med Chem 2005;12(10):1161-208.

2. Fenninger LD, Mider GB. Energy and nitrogen metabolism in cancer. Adv Cancer Res 1954;2:229-53.

3. Clarkson D, Burchenal JH. Preliminary screening of antineoplastic drugs. Prog Clin Cancer 1965;1:625-9.

4. Prasad SB, Giri A. Antitumor effect of cisplatin against murine ascites Dalton's lymphoma. Indian J Exp Biol 1994;32(3):155-62.

5. Tausz M, Wonisch A, Grill D, Morales D, Jiménez MS. Measuring antioxidants in tree species in the natural environment: From sampling to data evaluation. J Exp Bot 2003;54(387):1505-10.

6. Cai Y, Luo Q, Sun M, Corke H. Antioxidant activity and phenolic compounds of 112 traditional Chinese medicinal plants associated with anticancer. Life Sci 2004;74(17):2157-84.

7. Hammer KA, Carson CF, Riley TV. Antimicrobial activity of essential oils and other plant extracts. J Appl Microbiol 1999;86(6):985-90.

8. Subramani SP, Goraya GS. Some Folklore medicinal plants of Kolli hills: Record of a Watti vaidyas Sammelan. J Econ Taxon Bot 2003;27(3):665-78.

9. Cowan MM. Plant products as antimicrobial agents. Clin Microbiol Rev 1999;12(4):564-82.

10. Demain AL, Sanchez S. Microbial drug discovery: 80 years of progress. J Antibiot (Tokyo) 2009;62(1):5-16.

11. Davies J, Davies D. Origins and evolutions of antibiotic resistance. Microbiol Mol Biol Rev 2010;74(3):417-33.

12. Ruddock PS, Charland M, Ramirez S, López A, Neil Towers GH, Arnason JT, et al. Antimicrobial activity of flavonoids from Piper lanceaefolium and other Colombian medicinal plants against antibiotic susceptible and resistant strains of Neisseria gonorrhoeae. Sex Transm Dis 2011:38(2):82-8.

13. Singh B, Singh S. Antimicrobial activity of terpenoids from
Trichodesma amplexicaule Roth. Phytother Res 2003;17(7):814-6.

14. Taleb-Contini SH, Salvador MJ, Watanabe E, Ito IY, de Oliveira DC. Antimicrobial activity of flavonoids and steroids isolated from two Chromolaena species. Rev Bras Cien Farm 2003;39(4):403-8.

15. Mandal P, Sinha Babu SP, Mandal NC. Antimicrobial activity of saponins from Acacia auriculiformis. Fitoterapia 2005;76(5):462-5.

16. Nazemiyeh H, Rahman MM, Gibbons S, Nahar L, Delazar A, Ghahramani MA, et al. Assessment of the antibacterial activity of phenyl ethanoid glycosides from Phlomis lanceolata against multiple-drugresistant strains of Staphylococcus aureus. J Nat Med 2008;62(1):91-5.

17. Chopra RN, Nayar SL, Chopra IC. Glossory of Indian Medicinal Plants. New Delhi: Council of Scientific and Industrial Research; 1956. p. 256-7.

18. Kamboj VP. Herbal medicine. Curr Sci 2000;78(1):10.

19. Western Ghats. Available from: https://www.en.wikipedia.org/wiki/ Western Ghats.

20. Roy PS, Kushwaha SP, Murthy MS, Kushwaha D, Reddy CS, Behera $\mathrm{MD}$, et al. Biodiversity Characterization at Landscape Level: National Assessment. Dehradun, India: Indian Institute of Remote Sensing (IIRS); 2012. p. 140.

21. Pullaiah T. Biodiversity in India. Vol. 4. New Delhi: Regency Publications; 2006. p. 281-2

22. Yesodharan K, Sujana KA. Wild edible plants traditionally used by the tribes in Parambikulum Wildlife Sanctuary, Kerala, India. Nat Prod Radiance 2007;6(1):74-80.

23. Ashwathanarayana R, Naika R. Comparative study of different solvent extract of Olea dioica Roxb. Western Ghats, Karnataka, against selected plant and animal pathogenic bacteria. J Pharm Bio Res 2015;3(1):217-22.

24. Ashwathanarayana R, Naika R. Preliminary phytochemical and antimicrobial properties of Olea dioica Roxb bark extract collected from Western Ghats, Karnataka, India. J Pharmacogn Phytochem 2015:4(4):156-60

25. Available from: http://www.toxicologycenter.com.

26. Bhat KG. Flora of Udupi. Udupi: Indian Naturalist; 2003.

27. De-Castro MD, García-Ayuso LE. Soxhlet extraction of solid matrices: 
an outdated technique with a promising innovative future. Anal Chim Acta 1998;369:1-10.

28. Singleton VL, Rossi JA. Colorimetry of total phenolics with phosphomolybdic-phos photungstic acid reagent. Am J Enol Vitic 1965; $16: 144-58$

29. Zhishen J, Mengcheng T, Jianming W. The determination of flavonoid content in mulberry and their scavenging effects on superoxide radicals. Food Chem 1999;64(4):555-9.

30. Prieto P, Pineda M, Aguilar M. Spectrophotometric quantitation of antioxidant capacity through the formation of a phosphomolybdenum complex: Specific application to the determination of vitamin E. Anal Biochem 1999;269(2):337-41.

31. Oyaizu M. Studies on products of browning reaction: Antioxidative activities of products of browning reaction prepared from glucosamine. Jpn J Nutr 1986;44(6):307-15.

32. McCord JM, Fridovich I. Superoxide dismutase. An enzymic function for erythrocuprein (hemocuprein). J Biol Chem 1969;244(22):6049-55.

33. Kunchandy E, Rao MN. Oxygen radical scavenging activity of curcumin. Int J Pharm 1990;58:237-40

34. Ohkawa $\mathrm{H}$, Ohishi N, Yagi K. Assay for lipid peroxides in animal tissues by thiobarbituric acid reaction. Anal Biochem 1979;95(2):351-8.

35. Alzoreky N, Nakahara N. Antioxidant activity of edible Yemeni plants evaluated by ferryl myoglobin/ABTS assay. Food Sci Technol Res 2001;7:141-4

36. Dinis TC, Madeira VM, Almeida LM. Action of phenolic derivatives (acetaminophen, salicylate and 5-aminosalicylate) as inhibitors of membrane lipid peroxidation as peroxyl radical scavenging effects. Chem Pharm Bull 1994;36:2090-7.

37. Moldeus P, Hogberg J, Orrhenius S, Parker FS. Methods in Enzymology. Vol. 52. New York: Academic Press; 1978. p. 60-71.

38. Shrivastava $\mathrm{S}$, Ganesh N. Tumor inhibition and cytotoxicity assay by aqueous extract of onion (Allium cepa) \& garlic (Allium sativum): An in-vitro analysis. Int J Phytomed 2010;2:80-4

39. Ramnath V, Rekha PS, Kuttan G, Kuttan R. Regulation of caspase-3 and Bcl-2 expression in Dalton's lymphoma ascites cells by Abrin. Evid Based Complement Alternat Med 2009;6(2):233-8.

40. Hajighasemi F, Mirshafiey A. Propranolol effect on proliferation and vascular endothelial growth factor secretion in human immune competent cells. J Clin Immunol Immunopathol Res 2010;2(2):22-7. 